\title{
Representations of gender in executive offices
}

\author{
Representações de gênero em cargos de gestão \\ Representaciones de género en puestos directivos
}

Received: 12/22/2020 | Reviewed: 12/29/2020 | Accept: 12/30/2020 | Published: 04/01/2021

\author{
Jair Modesto Filho \\ ORCID: https://orcid.org/0000-0002-8345-562X \\ Centro Universitário Una, Brazil \\ E-mail: jair.modesto.filho@hotmail.com \\ Adriane Vieira \\ ORCID: https://orcid.org/0000-0001-7552-5491 \\ Universidade Federal de Minas Gerais, Brazil \\ E-mail: vadri.bh@gmail.com \\ Alexandre de Pádua Carrieri \\ ORCID: https://orcid.org/0000-0001-8552-8717 \\ Universidade Federal de Minas Gerais, Brazil \\ E-mail: alexandre@face.ufmg.br
}

\begin{abstract}
Based on the critical discourses analysis, this study reached the goal of thinking about what was said and not said concerning the attributes of masculinity and femininity that configure the modes of management in organizations. This research is based on the analysis of discourse as the objective of understanding the meaning of the enunciation by means of the enunciative marks given and not mentioned. Eight semi-structured interviews were conducted based on a guiding script. A technique used to select the subjects was the snowball. What was said by four male managers and four female managers confirms that for women the male attributes are best suited for the management, and for men feminine attributes as emotional involvement and commitment contribute to a more humanized management. What is implied is that the male predominance in management positions is due to the inability of women conquer the professional spaces as men, because they do not have the right genetic heritage or because they need to be protected by men, who are 'natural born leaders'.
\end{abstract}

Keywords: Gender; Social representation; Manager; Power relations; Critical discourse analysis.

\section{Resumo}

A partir da análise crítica dos discursos, este estudo atingiu o objetivo de refletir sobre o que foi dito e não dito sobre os atributos de masculinidade e feminilidade que configuram os modos de gestão nas organizações. Esta pesquisa ancorou-se na análise do discurso com o objetivo de compreender o sentido do enunciado por meio das marcas enunciativas ditas e não ditas. Foram realizadas oito entrevistas semiestruturadas a partir de um roteiro norteador. A técnica utilizada para selecionar os sujeitos foi a bola de neve. O que foi dito por quatro gerentes do sexo masculino e quatro gerentes do sexo feminino confirma que para as mulheres os atributos masculinos são os mais adequados para a gestão, e para os homens atributos femininos como envolvimento emocional e comprometimento contribuem para uma gestão mais humanizada. O que está implícito é que o predomínio masculino nos cargos de chefia se deve à impossibilidade de as mulheres conquistarem os espaços profissionais como homens, por não possuírem o patrimônio genético adequado ou por necessitarem ser protegidas pelos homens, que são 'líderes natos'.

Palavras-chave: Gênero; Representação social; Gerente; Relações de poder; Análise crítica do discurso.

\section{Resumen}

A partir del análisis de los discursos críticos, este estudio alcanzó el objetivo de pensar lo que se dijo y no se dijo sobre los atributos de masculinidad y feminidad que configuran los modos de gestión en las organizaciones. Esta investigación se basó en el análisis del discurso con el objetivo de comprender el significado del enunciado a través de las marcas enunciativas habladas y tácitas. Se realizaron ocho entrevistas semiestructuradas con base en un guión de preguntas orientativas. La técnica utilizada para seleccionar a los sujetos fue la bola de nieve. Lo dicho por cuatro gerentes masculinos y cuatro gerentes femeninas confirma que para las mujeres los atributos masculinos son los más adecuados para la gestión, y para los hombres los atributos femeninos como implicación emocional y compromiso contribuyen a una gestión más humanizada. Lo que se implica es que el predominio masculino en los puestos directivos se debe a la incapacidad de las mujeres de conquistar los espacios profesionales como hombres, porque no tienen la herencia genética adecuada o porque necesitan ser protegidas por hombres, que son 'líderes natos '.

Palabras clave: Género; Representación social; Gerente; Relaciones de poder; Análisis crítico del discurso. 


\section{Introduction}

The objective in this study was to describe what are the attributes that participate in the construction of social representations about the modes of female and male management and to analyze the interactions that are established from these representations. Our study is based on poststructuralist contributions articulated to the theory of social representations, considering reality as a social and subjective construction, which allows to work the symbolic universe in the organizational field. Critical post-structuralist studies are not intended to discover and reveal truths; rather, they embrace alternative ways of problematizing the object under study, understanding that it is possible to produce provisional and temporary knowledge and responses.

Beck and Guizzo (2013), Härkönen, Manzoni and Bihagen (2016), Devi and Somokanta (2016) and Ribeiro, Zanini, Silva and Dias (2020) we try to show that in the study of gender relations it is not possible to accept simplistic visions, which postulate that biological sex confers on men and women characteristics that differentiate them and make them unequal, since the greatest differences are built by the cultural elements.

Culture is a collective phenomenon and corresponds to thought patterns, feelings and behaviors installed in the mind, the result of processes acquired initially in the family, and which have continuity in the different environments in which the individual inserts throughout his life. According to Chies (2010) and Coffey-Glover (2019), the stereotyped and sexist conceptions of what society expects of girls and boys begin to be developed in childhood and continue in adult life, especially in the professional field, reaffirming at all times the relations of power between genders in all social classes. In assuming managerial positions in organizations, for example, women can learn to perform a masculine performance (Butler, 2016) by acquiring behaviors considered different from what was socially established as female. Women then seek to performatically express an identity of the dominant gender in order to attempt to establish a certain gender equality in an environment that is guided by the male domain (Anderson \& Klofstad, 2012; Vieira, Carrieri, Monteiro, \& Roquete, 2017; Stoet \& Geary, 2018).

In relation to male domination, Beauvoir (1989) states that through family experience the girl realizes that the world belongs to men and they must be respected. Children's literature, mythology, tales and narratives reflect the myths created by the desire of men, and it is through the male eyes that she explores and glimpses the world and projects her destiny, according to the author.

Male domination is a particular form of symbolic violence, according to Bourdieu (1989), imposed by means of legitimized meanings, so as to disguise the power relations that sustain violence itself. Still according to the author, these unequal relations of power are based on an acceptance of the dominated groups, but not necessarily conscious, therefore, we can be led to believe in the freedom to think and act without taking into account that this thought and action are marked by interests, prejudices, world views and opinions of those who dominate. Physical violence has also been present in the lives of these women since adolescence. They find it difficult to talk about it with other people, even with family, close friends or even the school (Mateus et al., 2020).

The movement for feminine emancipation began in the twentieth century, but it adopted different outlines depending on the sociocultural characteristics of the countries and their regions. As a consequence, it deepened discussions about men and women in society, allowing a conceptual difference between sex and gender, the first being used only to refer to biological differences, and the second to address the sociohistorical context that produces these differences (Butler, 2016). Over the years it has been possible to observe significant changes in the position of women in the labor market. They have been highlighting and gaining space in the organizational and political field, however, they still suffer from inequalities in power relations with the opposite sex (Rice \& Barth, 2016). Research on gender inequalities in the labor market reports a major female 
disadvantage, pointing to the fact that men receive better rewards at work in terms of income, status and promotion (Watt, 2010), which explains, in part, the fact that women find it more difficult to rise to managerial positions.

Drawing on the theory of social representations, it is possible to argue that these differences are historically constructed, consolidating gender inequality at work (Butler, 2016; Albuquerque \& Braz da Silva, 2019). Gender representations are therefore constructed in our daily lives and are related to stereotyped ideas that guide behaviors about what would be characteristic of the 'masculine' and 'feminine' (Gartzia \& van Egen, 2012; Drydakis et al., 2018). We should think of female emancipation as a struggle for the deconstruction and denaturation of the binary, universalist and essentialist oppositions that reduce women to a gender / gender dichotomy, disregarding an entire production discursive (discursive practice) culturally defined and maintained by social relations (Brandt, 2011; Barone, 2011; Mihăilă, 2016). For this reason, to carry out our study we follow the path of Discourse Analysis, analyzing and discussing two enunciative marks of the text that confirm the said and the not said about the attributes of gender and the modes of management, that is, the information stated explicitly in the text, as well as those that are implied, implicit or presupposed (Pauliukonis, 2006), which contribute to the maintenance of relations of inequality and domination of one gender over the other.

Our research assumption is that, as pointed out in the studies by Carrieri, Diniz, Souza and Menezes (2013), Anderson and Klofstad (2012) and Gartzia, and van Egen (2012), executive women tend to admit that what is usually interpreted as male behavior, is seen and seen by them as professionalism. And that, men continue to guard their prejudices, although they are forced to admit that some naturally feminine traits end up being important to compose a managerial profile of success in the teams, especially when there is a feminine predominance in the organizations. Thus, we believe that unequal relations of access and progression in managerial positions tend to be silenced or minimized in discourses.

We will present, next, the conceptual debate on gender and social representations, and later the methodological course and the analysis of the discourses that generated the discussion about the social representations on the attributes of gender linked to the management.

Through the discourses, it was possible to have a dimension of the role that men and women play in the professional sphere, taking in consideration the cross-linking of representations with other factors, such as power relations and identification, or not, with their gender condition.

\section{Methodological Course: Analysis of the Senses Produced}

This research was anchored in discourse analysis in order to understand the meaning of the utterance through the said and unspoken enunciative marks. Starting from the conceptions of Foucault (2007), we understand that discourse represents a form of power present in the social field, which, when it reaches the status of a dominant order, is controlled, filtered and selected, establishing what is right and what is wrong, using the enunciators themselves to perpetuate in power and restrict possible disputes. Therefore, those who wish to be accepted by society must adopt the dominant discourse and submit to the rules defined by it. According to Foucault (2007), discursive formations condition, control and delimit the way of seeing the facts, of conceptualizing things and social practices, revealing the proximity between discourse and power.

As Pauliukonis (2006) and Coffey-Glover (2019), (implicit, presupposed, implied), in an attempt to approach discourse as a social practice, constructed in the connection between discourse as structure (intra-discourse) and interdiscourse, that is, discourse within discourse, because it has already been said elsewhere.

We conducted semi-structured interviews using a guiding script and not closed questions, since it is considered that the discursive productions originated at the moment of the interview produce new meanings constructed by the interviewees. 
All of them have been recorded and transcribed in full.

The technique used to select the subjects was the 'snowball' (Dusek, Yurova, \& Ruppel, 2015) as appropriate in cases where it is not possible to obtain much background information on the context under investigation. By means of this technique, some subjects are identified and they are asked to indicate others until reaching the point of redundancy in relation to the data. In this research, it was interesting to have access to people who had held managerial positions for at least five years and who were employed at the time of data collection.

\section{Results and Discussion}

We sought to select a heterogeneous sample, taking into account the age, the time in the managerial position, the sex and the insertion in different sectors of the economy. Table 1 presents information about the sociodemographic profile of the interviewees. We chose to use codes to identify managers and managers, preserving their identities.

Table 1. Sociodemographic profile of research subjects.

\begin{tabular}{ccccccc}
\hline Code & Ocupation & Education & Sector & Segment & Age \\
\hline E1 & Director & Law & Private & Industry & 43 \\
E2 & Director & Psychology & Private & Higher education & 41 \\
E3 & Manager & Psychology & Private & Service & 42 \\
E4 & Director & Engineering & Private & Construction & 33 \\
E5 & Director & Economy & Private & Higher education & 51 \\
E6 & Director & Engineering & Private & Construction & 34 \\
E7 & Superintendant & Economy & Private & Services & 46 \\
E8 & Congressman & Math & Public & Politics & 60 \\
\hline
\end{tabular}

Source: Authors.

As can be seen in Table 1, five respondents were company directors, one was a manager, one was a superintendent and one held the position of state deputy. As for education, two were graduated in psychology, two in economics, two in engineering, one in law and one in mathematics. Two eight respondents, only one held the position in the public sector, two worked in the higher education sector, two in civil construction, two in the service sector, one in the industrial sector and one in the political sector. As for age, two were over 50 years old, four were between 41 and 46 years old, and two of them were 33 and 34 years old.

We begin this item with a brief description of the family and professional history of each subject of the research, and then we stick to the attributes of masculinity and femininity proper, since the representations are socially constructed from our birth, beginning with the culture and habits of their own family.

E1 has a degree and a doctorate in law, her father was a graduate in administration and died when she was a child. Her mother and stepfather have no upper level. She lives a stable and childless union. She dedicates herself entirely to work and considers herself a perfectionist in what she does. The people who most influenced her professional choices were her law professors.

E2 is a graduate in psychology and works in a teaching institution. She is considered a strong woman, whose trait was inherited from the Lebanese women of the family, especially of the mother, a lyric singer, 'strong and independent', that traveled the country making presentations. In the profession, the major influences were all masculine.

E3 is a psychologist and HR manager, married and has two children. Northeastern parents migrated to São Paulo. Her 
father was self-employed and her mother sewed clothes and produced snacks to sell. Those who most influenced her academic and professional choices were an executive and a business president, with who she worked, who showed her the importance of communicating and connecting HR with company strategies and results.

E4's father is an engineer and founder of company, and the mother housewife. She studied engineering under the influence of her father and became one of the directors of the family business. It also received a lot of influence from teachers during college, and if it were not for the family would have followed the academic career.

E5 graduated in economics and began his career as an analyst at a major electric power company. His mother is a prosecutor and the father is a business administrator. E5 has a stable homoaffective relationship with no children. He was promoted to director and then moved to the teaching area. The people who most influenced his professional life were father and mother, who appreciated the good academic background. In the business environment he met several people who served as an example, the vast majority of men.

E6 is the son of a civil engineer father and mother housewife. He is married and has a daughter. The father exerted great influence in the choice of the profession and until today works in the company founded by him. He even thought about pursuing psychology, but as the only son he was the 'natural heir' of business. The decision was made by his mother, who according to him was very influential in the decisions of the family and imposed more than the father. The two sisters work in the company as well, subordinated to him.

The father of E7 has a senior level and is retiring from the career built in the public area. His mother has a high school degree and was an entrepreneur in the sales field. He is married and has two children, the wife is finishing upper level. E7 graduated in economics, has worked in several large companies in the commercial area and is superintendent of a health care provider.

E8's mother is a retired teacher and the merchant father. He is married a second time. He has two children from the first marriage and one from the second. He was a teacher, trade unionist, councilman, state and federal deputy. In the political environment he lives more with men, but his office is very heterogeneous.

Once the description is complete, we will now turn to the topic of gender attributes and management modes. During the interviews we sought to understand the perception of men and women as to the attributes of masculinity and femininity that permeate the organizational world, especially regarding the managerial position, composing a masculine and feminine management mode. The conversation was conducted in such a way as to look for a description of how those representations were constructed by the subjects over time, and the people and situations that most influenced in that construction. Table 2 summarizes the attributes of femininity and masculinity manifested in management, highlighted by the interviewees. 
Table 2. Attributes of femininity and masculinity for the research subjects.

\begin{tabular}{|c|c|c|}
\hline Subject & Feminility & Masculinity \\
\hline E1 & $\begin{array}{l}\text { Ease of doing several things at once, ease of interpersonal } \\
\text { relationship, ability to complicate situations. }\end{array}$ & Practicity. \\
\hline E2 & Fragility, competition with other women & $\begin{array}{l}\text { Determination, ability to position, corporate, firm, direct, } \\
\text { objective. }\end{array}$ \\
\hline $\mathbf{E 3}$ & Motherhood, cooperation, listening. & $\begin{array}{l}\text { Result, effort, courage, pragmatism, ease of exposure, ability to } \\
\text { earn money. }\end{array}$ \\
\hline E4 & Vanity, I like to take care of myself. & I do not know how to distinguish. \\
\hline E5 & $\begin{array}{l}\text { Careful, detailed, preoccupied with the result, risk a little less, } \\
\text { be more careful, sharper perception. }\end{array}$ & More concerned with himself, generalist. \\
\hline E6 & Passive, less ambition, good memory, care for things. & Leadership \\
\hline E7 & $\begin{array}{l}\text { Passion for what you do, emotional involvement, discipline, } \\
\text { more commitment, will to do that well done. }\end{array}$ & $\begin{array}{l}\text { Little commitment, emotionally distant, know how to handle } \\
\text { obstacles better, more clarity and ease in making decisions. }\end{array}$ \\
\hline E8 & $\begin{array}{l}\text { Skill in negotiations, firmness in your convictions, dislike } \\
\text { facing. }\end{array}$ & Persistent, support the clash. \\
\hline
\end{tabular}

Source: Authors.

The discourses of both genders (Table 2) reveal similarities in the way they perceive the feminine and masculine attributes, reaffirming that the representations are socially constructed. They also provide elements for analyzing what individuals and groups think about behavioral styles and their influences on management.

The E2 discourse, for example, reflects a history of strong identification with the masculine attributes: "determined, firm and objective". She goes so far as to show some contempt for female behavior that she considers "complex and competitive", implying that there is envy and lack of solidarity among women. It is not surprising, then, that she can easily describe the attributes of masculinity, but she cannot do the same when it comes to femininity. She says that "women have to be more determined and position themselves more like men". Note that she uses the verb in the imperative, expressing order and determination, and also says that she must "kill a lion a day" to prove that she has the same level of competitiveness as men. This allows us to assume that the work environment is the space of competitions and dominations, where power struggles occur (Bourdieu, 1989; Montesanti \& Thurston, 2015; Härkönen et al., 2016; Devi \& Somokanta, 2016), and often permeated by exclusionary and prejudiced practices, in which language itself demarcates the places of the genres through the use of analogies, for example (Albuquerque \& Braz da Silva, 2019).

She adds: "Sometimes praising my physical appearance even bothers me. I want to be seen by what I represent at work". What is said in the speech segments of E2 is that for a woman to succeed professionally it is necessary to "exacerbate these so-called masculine characteristics". It is inferred, then, that the female success is related to the capacity to incorporate socially considered masculine attributes (determination, firmness and objectivity), denying those that are feminine (Gartzia \& van Egen, 2012; Stoet \& Geary, 2018; Drydakis et al., 2018).

E2 adds that: "for men everything is easier. They may even have a love affair at work, incidentally, those who do not invent, because it is part of their social construction". The unspoken, or implicit, is that executive women fear that others think they have ascended the hierarchy by their physical attributes, for this, they must separate the amorous conquests of the professionals; another presupposition is that in the masculine world, on the contrary, virility is the ultimate symbol of success, which precedes and may even be a prerequisite for professional success. 
A different situation is experienced by E4, who needs to affirm her femininity because she chose a masculine predominance (engineering) profession, said in the speech segments: "I made engineering, that everyone associates more with the masculine side" and "I think I'm very feminine, for example, I'm vain and I like to take care of myself ". It is understood that men are not vain, and this is an attribute that could be used to distinguish between genders. In another segment of the discourse, to explain why her firm hires more men than women, E4 resorts to rational logic and reduces the complex power-togender relationship in the workplace to an administrative one: "I do not believe it's prejudice, I believe it is a logistical problem. You only have one structure of accommodation and bathroom, and when you have men and women need to have a separate structure". If the saying is "I do not believe it to be prejudice", it is understood that this prejudice is present, not necessarily spoken or denounced, but should be denied. In the sequence she says: "Today, our highest positions are occupied by men, but not because they are men, but because they have conquered this place. It would be open to women as well. I'm even their manager, right?". In this segment of speech she asks the interviewer to confirm that she is a manager, because she has conquered this space like men, not because she is the heir of a business founded by her father, which is duly silenced at that moment. On the assumption, the masculine predominance is due to the incapacity of the women to conquer the professional spaces like the men.

The discourse of $\mathrm{E} 1$ is also characterized by denials that reaffirm the differences: "I say that I am a half-man woman. Even because in the area of law all are equal, there are no differences". This segment highlights the need for women to incorporate masculine attributes (being half-men) to succeed in leadership, being a very effective use mechanism to keep women out of the upper levels of corporate management, as well as an attempt to establish gender equality in an environment that is driven by the male domain (Gartzia \& Egen, 2012; Galdi, Cadinu, \& Tomasetto, 2014; Butler, 2016, Mihăilă, 2016).

When asked if the behaviors of men and women would be the same, E1 replies, "I think they should be." The use of the future of the preterit holds the nonsense that this equality, in fact, does not exist. In another segment of the E1 discourse he says that "society still sees women as the fragile sex, and silences their own opinion". She adds, "I've always enjoyed working with men. They are more practical. Women complicate certain situations, but, as I said, I do not see much of this distinction, I like working with good people". Men are therefore presented as good people, not because they are men, but because they do not complicate situations like women, because they are "more practical". The term 'practical' brings the implicit idea that men think and act according to reality and pursue a useful end in their actions, so they are better prepared for the management.

E3 brought the maternity attribute to the speech: "the world of work is very masculine, and I only came across my feminine traits after motherhood. I'm focused on results, I'm pragmatic and objective". Like E1, it makes it clear that men are naturally fit for management, and that if women who want to compete with them must have the same attributes (pragmatism and objectivity). What is implicit is that attributes such as affection and care, awakened by motherhood, concern the private sphere and are not pertinent to the management.

Studies show that as they climb higher ranks in the hierarchy, women end up incorporating masculine attributes to escape the stereotypes of fragility (Gartzia \& van Egen, 2012; Carriere et al., 2013; Butler, 2016; Drydakis et al., 2018), for this reason, the conflict to be faced by women is based on the recognition that effective leadership does not necessarily pass through possible exclusively male attributes (Moscovici, 2007; Montesanti \& Thurston, 2015; Albuquerque \& Braz da Silva, 2019). However, it is necessary to recognize that it is difficult to fight symbolic violence (Bourdieu, 1989) present in societies that have the patriarchal model as a reference, such as the Brazilian (Miguel, 2017).

Male respondents, on the other hand, reaffirm gender differences supported by the same attributes pointed out by women, but bring different connotations. E6 and E8, for example, have discourses marked by stereotypes and prejudices, while 
E5 and E6 adopt more critical positions, which refer to power relations between genders.

According to E6, leadership positions are held by men, but "you do not know for sure why this happens, whether it's because of a cultural or DNA condition". In this section of the speech he opens the possibility of social construction of gender differences, but concludes the phrase with the possibility of 'genetic inheritance', as if there was one for leadership, present only on the $\mathrm{Y}$ chromosome (male). What is implicit in the discourse is that this second alternative neutralizes the socio-cultural differences resolving possible conflicts of power, since what was previously defined by biology is not liable to change or blame.

He further explains that the main masculine attribute is leadership, moreover, classifies women "as passive and with less ambition, perhaps because they are created with that paternal figure who is a leader and who gives the guidelines". In another segment of speech he identifies some qualities in women, such as "good memory and more care for things". The unsaid is that the act of caring is banal and of little social value, translated by replacing the words 'son, husband and house' with 'things'. Lest his company be said to be sexist, he reports that "there are few women in engineering, but we have women here". What is implied, therefore, is that although they do not have much affinity with engineering, it is necessary to give them jobs, because they need to be 'protected' and 'led' by men.

E8 states with certainty that politics is a masculine stronghold because it is "very hard," and justifies that "women have more difficulty sustaining confrontations and clashes", but at the same time "she has more persuasiveness". It is therefore understood that it is 'fragile' but 'useful' at certain stages of the negotiation. For him, political life demands a condition of freedom that women cannot enjoy ("less available"), the unspoken is that being or not being available is a social imposition and not an individual choice: "The man travels more, he is looser. Sometimes he stays two weeks away from home. So the woman is less available. Political life is made much for man". In addition, it is understood that what constitutes the way of doing politics in Brazil is not the practice of mediation of conflicts, of communication, interaction and exchange, but rather the struggle, the struggle, that is, the opposition, the reaction and resistance. This explains, in part, the weak female representation in the National Congress and in other spaces of political representation of public life, associated with the gender stereotypes present in the political news, which help to constrain women's political action (Meeks, 2012; Rezende, 2017).

What brings the two discourses closer (E6 and E8) is the use of gender stereotypes to address the management mode, saying that while male leadership should emphasize the achievement of organizational goals, female leadership should emphasize people and relationships (Gartzia \& van Egen, 2012; Anderson \& Klofstad, 2012; Carrieri et al., 2013), incorporating explicitly and implicitly the social representations of what it is to be man and woman in our society.

E5 considers that in Brazil "machismo is imperative", and that "it is still common these days to hear a man speaking that he does not work with a woman because she is very emotional, or because she is going to get pregnant and leave it in her hand". The subjects are "Brazil and the others", excluding him from the scene. The assumption is that the woman is not rational, in addition, there is the idea of abandoning (leaving her in the hand) one person (manager or colleague) depending on another (husband or children), of course, something another man (married and with children) would not do, for giving priority to work. In the sequence, E5 says that there is a difference between the thought and the way of acting feminine and masculine, but, its description also contains a sense of complementarity: "the woman is much more careful, detailed, preoccupied with the result, risks a little less, has more care and keener perception. The man risks more, is more concerned with himself, is a generalist". The attributes chosen are those traditionally used to distinguish one gender and the other, but softened by the expressions "more" or "less". In addition, he is able to turn a critical eye on female behavior. 
If companies had more women on the board, relationships would be better because they like to train people. There are also women who mimic male behavior because they think they can dig more space because it does not have much space. A woman will not be a man in business and not a man will be a woman in business. (E5)

What E5 says is that there are few women in managerial positions in companies, and they are naturally apt to generate and educate human beings, in companies or at home. To win higher ranks, some copy male behavior. The unsaid is that Brazilian men are not responsible for education (children, employees) and that they are stronger and more aggressive.

E7 presents similar discourse, using the same attributes to differentiate the genres: "the woman has passion for what she does, emotional involvement, discipline, commitment and is more emotional. Men are less committed and emotionally distant, they know how to deal with obstacles better, they have more clarity and ease in making decisions". What is said in this segment of discourse is that what distinguishes the mode of masculine and feminine management is the separation between emotion and reason, not to affect the capacity of decision and leadership; which is a simplified view of power relations between genders. In another segment he emphasizes the relation of complementarity between the genres, saying that the "winner" is the one who can control their emotions.

I think that when a woman manages to have some of that emotional detachment she becomes a successful executive. When a man has a slightly more affective involvement it also helps. Then they become full-fledged professionals because the higher positions demand more coolness to deal with the challenges. (E7)

Similarly to E3, with regard to motherhood, E7 refers to the importance of the role of father in her life, and just as E5 says that men can move away from the family relationship by job and career: "Today I take my boys to school, I go to school, I like to have lunch at home whenever possible, but I have not always been like this. During a good period in my career it was normal for me to be absent". The fact that today is a present father does not mean that E7 works less than women, nor does he assume more responsibilities in the domestic space (Venturi \& Oliveira, 2016; Miguel, 2017), only reflects that the greater participation of the man in the task of childcare is an act of voluntariness and not of obligation. On the meaning of motherhood for the woman, he says: "there comes a certain moment that she ('woman') begins to weigh it ('motherhood') more than man. And then she herself often imposes a limit and decides not to go further ('in the career'). He finds himself forced to give up something or other". The conflict that arises in the relation between motherhood and career is brought in this segment of discourse by the masculine gaze. What is implicit is that motherhood is socially required of women, but not of men, and that this ends up becoming a major dilemma, the outcome of which is most often the sacrifice of the career.

In general, what was silenced in the discourses was the conflicts resulting from unequal relations of power. If we treat the issue of leadership as a sub-theme of power relations, we have identified that male domination is sometimes viewed as part of culture and can hardly be modified, at other times it is also seen as naturalized (linked to DNA), so it can not be blamed.

Social and organizational inequities can also be interpreted as simply a matter of developing professional skills, and therefore of the inability of women to compete and gain space in organizations because they do not strive as much as men do not enjoy the freedom to stay away from home and children, are fragile, submissive and complicated. The outputs pointed out by the interviewees are always individual. There is no room for collective struggle or for the free and open expression of the dominated condition. What remains is almost silence, in the form of a small complaint if one is interested in listening: each one who kills his own "lion" and is "reproductive" of socially dominant behavior. 
The perspective of complementarity was present only in masculine discourses, in the sense that women should take a little more risk and maintain emotional detachment in decision making, while men should be less individualistic and more involved and emotionally involved with people and with the work. In short, leadership, decision-making, strength, and persistence are still associated with masculinity, while interpersonal, listening and listening skills are still associated with the female universe (Moscovici, 2000; Gartzia \& Egen, 2012; Mihăilă, 2016).

\section{Final Considerations}

Based on the strategy of discourse analysis, this study fulfilled the mission of reflecting on the said and the unsaid as to the attributes of masculinity and femininity that configure the modes of work management. The discourses of the managers of both genders revealed similarities, confirming that the representations of gender are socially constructed. They also provided elements for the analysis of what individuals and groups think about behavioral styles and leadership in organizations. What has been said confirms the presupposition of this research.

Starting from the sayings, the managers reveal their own prejudices regarding the feminine gender, highlighting the attributes of fragilities, competition and capacity to complicate the situations in the work. While men are seen by them as practical, determined, firm, objective, direct, courageous, focused on results, outstanding ability to earn money, and naturally fit for leadership. Although they emphasize the ease that women possess of doing several things at the same time, of maintaining good interpersonal relationships, of cooperating and listening, what is implied in the speeches is that these attributes are not the most important ones for the management, nor the most valued in the world of work.

The sayings of managers go in the same direction. Some discourses are more emphatic in explaining that women are 'naturally' unfit for management and leadership (passive, unambitious, emotional, risk-averse and confrontational), others indicate the complementarity of male and female attributes in the composition of management profile, especially in terms of discipline, commitment, negotiation skills and firmness of beliefs.

They also point out that if women want to succeed in the executive world they must exercise more control over emotion. The reverse is also true, that is, men would need to exercise affectivity. This discourse, however, contains a simplification of domination in gender relations, limiting differences to the classic clash between emotion and reason. As if it were enough for each individual, to develop more or less some attributes, unifying and equating the most appropriate behaviors for a successful management.

What is also implicit in the managers' discourses, on the one hand, is a strong tension about feminine sensuality and sexuality, expressed by the fear of not being considered serious and competent professionals, due to beauty and sensuality. On the other hand, to become asexual beings or even confused with other men, having to affirm their femininity by vanity, although at times they prefer to engage in professional activities (or have hobbies historically and socially associated with the masculine universe.

In this crossbreeding is that maternity is explicitly and implicitly obligatory for women, while men, even married and with children, enjoy freedom and autonomy not to actively participate in daily family life, because work and career have priority. Those women who rebel and prioritize their career often conflict with having to give up their children, and when they choose to reconcile the roles of professional and mother, they come into contact with attributes and behaviors that they have repressed.

On the assumption, male dominance in managerial positions is due to the inability of women to conquer occupational spaces like men or because they do not have the right genetic inheritance for it and need to be protected and led by men. 
Another unsaid is that the attributes that most often characterize the feminine way of being, such as the ability to care for and educate, have little social value.

What these discourses silence is the recognition that effective leadership and professional management do not involve the incorporation of attributes traditionally associated with the masculine gender, but rather through the explanation and exposure of suffering and injustice that need to gain more space in the media and in the debates. What we identify with this study is that unequal relations of power, access, and progression in executive positions tend to be ignored or minimized in both men's and women's discourses.

This paper allowed to reveal a little of what is said and, especially what is not said about the attributes of masculinity and femininity that are or are not valued in management. The challenge is to create public policies so that the themes of prejudice and gender inequality are addressed in work, education and society organizations in general, in a clear and transparent way, aiming at restricting discrimination.

The positive point of the research was to have confronted the visions of men and women on the subject of gender and work relations, as limitations we highlight the small number of subjects interviewed.

We suggest for the future work that the researches give voice to women and men inserted in different sectors of the economy, and also include people with different levels of schooling and different races.

\section{References}

Albuquerque, A. G., \& Braz da Silva, A. M. T. (2019). Gênero como objeto de pesquisa em Representações Sociais. Research, Society and Development, 8(7), e19871120. https://doi.org/10.33448/rsd-v8i7.1120

Anderson, R. C., \& Klofstad, C. A. (2012). Preference for leaders with masculine voices holds in the case of feminine leadership roles. PloS one, 7(12): e51216. https://doi.org/10.1371/journal.pone.0051216.

Bandura, A. (1977). Self-efficacy: toward a unifying theory of behavior change. Psychological Review, 82(2): 191-215. https://doi.org/10.1037/0033295X.84.2.191

Beauvoir, S. (1989). The second sex. New York: Random House.

Bourdieu, P. (1989). Social space and symbolic power. Sociological Theory, 7(1): 14-25. https://doi: 10.2307/202060

Brandt, M. J. (2011). Sexism and gender inequality across 57 societies. Psychological Science, 22: 1413-1418. https://doi.org/10.1177/0956797611420445

Butler, J. (2016). Frames of war: when is life grievable? 3th London: Verso Books.

Carrieri, A.P., Diniz, A.P.R., Souza, E. M., \& Menezes, R. S. S. (2013). Gender and work: representations of femininities and masculinities in the view of women brazilian executives. BAR Brazilian Administration Review, 10(3): 281-303. https://doi.org/10.1590/S1807-76922013005000002

Chies, P. V. (2010). Identidade de gênero e identidade profissional no campo de trabalho. Estudos Feministas, 18(2): 510-528. https://doi.org/10.1590/S0104$026 \mathrm{X} 2010000200013$

Coffey-Glover, L. (2019). Implicit masculinity: assuming and implying. In Men in Women's Worlds (pp. 187-214). Palgrave Macmillan, London.

Devi, W. P. \& Somokanta, T. (2016). Gender, technology, and work case of women employees in selected food processing industries in Manipur. Gender, Technology and Development, 20(1): 81-104. https://doi.org/10.1177/0971852415619497

Drydakis, N., Sidiropoulou, K., Bozani, V., Selmanovic, S., \& Patnaik, S. (2018). Masculine vs feminine personality traits and women's employment outcomes in Britain. International Journal of Manpower. www.emeraldinsight.com/0143-7720.htm

Dusek, G. A., Yurova, Y. V., \& Ruppel, C. P. (2015). Using social media and targeted snowball sampling to survey a hard-to-reach population: a case study. International Journal of Doctoral Studies, 10: 279-299. http://ijds.org/Volume10/IJDSv10p279-299Dusek0717.pdf

Eagly, A. H. (1997). Sex differences in social behavior: Comparing social role theory and evolutionary psychology. American Psychologist, 52(12): 13801383. https://doi.org/10.1037/0003-066X.52.12.1380.b

Foucault, M. (2007). A ordem do discurso. 15th São Paulo: Loyola.

Galdi, S., Cadinu, M., \& Tomasetto, C. (2014). The roots of stereotype threat: when automatic associations disrupt girls' math performance. Child Development, 85: 250-263. https://doi.org/10.1111/cdev.12128 
Research, Society and Development, v. 10, n. 1, e9910111430, 2021 (CC BY 4.0) | ISSN 2525-3409 | DOI: http://dx.doi.org/10.33448/rsd-v10i1.11430

Gartzia, L., \& van Engen, M. (2012). Are (male) leaders "feminine” enough? Gendered traits of identity as mediators of sex differences in leadership styles". Gender in Management, 27(5): 296-314. https://www.emerald.com/insight/publication/issn/1754-2413

Härkönen, J., Manzoni, A., \& Bihagen, E. (2016). Gender inequalities in occupational prestige across the working life: an analysis of the careers of West Germans and Swedes born from the 1920s to the 1970s. Advances in Life Course Research, 29: 41-51. https://doi.org/10.1016/j.alcr.2016.01.001

Jovchelovitch, S. (1995). Vivendo a vida com os outros: intersubjetividade, espaço público e representações sociais. Petropólis: Vozes.

Mateus, A. da S., Pessoa, B. G. F., Sousa, R. F. V., Nascimento, M. A. C. do., Monte, L. M. I. do., \& Nascimento, E. F. do. (2020). Violência nas relações afetivo-sexuais entre jovens com recorte de gênero: a partir de discursos de jovens piauienses. Research, Society and Development, $9(8)$, e725986123. https://doi.org/10.33448/rsd-v9i8.6123

Mateus, E., \& Resende, V. de M. (2015). O sistema posição-prática como categoria epistemológica: contribuições para análise de discurso crítica. Alfa, Revista Linguística, 59(3): 445-470. https://doi.org/10.1590/1981-5794-1509-1

Meeks, L. (2012). Is she "man enough"? Women candidates, executive political offices, and news coverage. Journal of communication, 62(1): $175-193$. https://doi.org/10.1111/j.1460-2466.2011.01621.x

Miguel, L. F. (2017). Voltando à discussão sobre capitalismo e patriarcado. Estudos Feministas, 25(3): 1219-1237. https://doi.org/10.1590/1806$9584.2017 \mathrm{v} 25 \mathrm{n} 3 \mathrm{p} 1219$

Mihăilă, R. (2016). Is the decrease in the gender wage gap the principal driver of the sustained rise in female labor market participation? Journal of Research in Gender Studies, 6(2): 146-172.

Miller, D. I., Eagly, A. H., \& Linn, M. C. (2014). Women's representation in science predicts national gender-science stereotypes: evidence from 66 nations. Journal of Educational Psychology. Advance online publication. https://doi.org/10.1037/edu0000005

Montesanti, S.R., \& Thurston, W.E. (2015). Mapping the role of structural and interpersonal violence in the lives of women: implications for public health interventions and policy. BMC Women's Health, 15(1): 100. https://doi.org/10.1186/s12905-015-0256-4

Morin, E. (2011). Introdução ao pensamento complexo. 4th Porto Alegre: Sulina.

Moscovici, S. (2007). Representações sociais. Investigações em psicologia social. 5th Petrópolis: Editora Vozes.

Pauliukonis, M. A. L. (2006). Texto e discurso: os processos de desvendamento inferencial. I Simpósio Internacional de Letras e Linguística (SILEL), 1., Uberlândia. Anais... Uberlândia: UFU, 2006. p. 1918-1925.

Rezende, D. L. (2017). Desafios à representação política de mulheres na Câmara dos Deputados. Estudos Feministas, 25(3): 1199-1218. https://www.jstor.org/stable/90013347

Ribeiro, L. P., Zanin, H. S., Silva, I. P., \& Dias, A. F. M. (2020). Políticas organizacionais de inclusão: práticas de respeito às minorias sexuais e de gênero. Research, Society and Development, 9(1), e176911894.http://dx.doi.org/10.33448/rsd-v9i1.1894

Scott, J. W. (1999). Some reflections on gender and politics. In: Ferree, M. M., Lorber J., \& Hess, B.B. (eds.). Revisioning Gender. Thousand Oaks, London, New Delhi: Sage Publications.

Stoet, G., \& Geary, D. C. (2018). The gender-equality paradox in science, technology, engineering, and mathematics education. Psychological science, 29(4), 581-593. https://doi.org/10.1177/0956797617741719

Venturi, G., Recamán M., \& Oliveira, S. (2013). Mulheres brasileiras e gênero nos espaços público e privado: uma década de mudanças na opinião pública. São Paulo: Fundação Perseu Abramo.

Vieira, A., Carrieri, A.P., Monteiro, P. R. R., \& Roquete, F.F. (2017). Gender differences and professional identities in health and engineering. BAR. Brazilian Administration Review, 14, 1-19. https://doi.org/10.1590/1807-7692bar2017160082

Watt, H. (2010). Gender and occupational choice. In: Chrisler, C. J., \& McCreary, D. R. Handbook of gender research in psychology. New York: Springer. p. $379-400$.

Wood, W., \& Eagly. A. H. (2015). Two traditions of research on gender identity. Sex Roles, 73: 461-473. https://doi.org/10.1007/s11199-015-0480-2 